\title{
Probable Impacts of Various Range Improvement Practices on Diffuse Salt Production
}

IRADJ K. HESSARY AND GERALD F. GIFFORD

\begin{abstract}
During 1976 a study of soil profile salt concentrations and probable salt loading by surface runoff was made on 73 range improvement sites in Utah, Colorado, New Mexico, and Arizona. The range improvement practices studied included gully plugs, contour furrowing, pitting, pinyon-juniper chaining, and various sagebrush-control treatments. Results of these studies indicated that the impact of gully plugs and contour furrows on potential diffuse salt production is somewhat variable and may in fact indicate that these treatments have only a minor potential impact, probably because the overland flow route is not a major source of diffuse salt movement, at least on lands sampled in this study. On pinyon-juniper sites and the various sagebrush treatments, the lack of difference in salt concentrations between treated and untreated sites was the only consistent trend. In general the measured salt concentrations in surface soils of either pinyonjuniper or sagebrush sites present a problem of little concern as related to salt production within the major river basins.
\end{abstract}

Salinity in the Colorado River is of major national concern, for not only has it resulted in losses to the regional economy, but also high salinity levels have aggravated relations with the Republic of Mexico. Even in its virgin state, the salt load of the Colorado River in its lower reaches was about 600-700 ppm. However, man's development of water resources has affected both the quantity and quality of water supplies. Salinity levels in the lower reaches of the river now average $850 \mathrm{pprn}$ with a predicted concentration of $1,300 \mathrm{ppm}$ by the year 2000 .

The sources and causes of dissolved solids within the Colorado River are of importance; for if they can be identified, strategies may be developed for effective management and control. In addition, this information would allow estimates to be made of downstream costs associated with upstream salt production, thus facilitating the development of economic trade-offs on a basin-wide level.

Recent estimates suggest that the largest single man-caused source of salinity is irrigation return flow, amounting to about a third of the total salt load. Natural sources such as salt wells and springs, plus concentration by evaporation, account for another third. The remaining salt load is attributed to diffuse sources

Authors are graduate research assistant and associate professor, rangeland hydrology, Watershed Science Unit, College of Natural Resources, Utah State University, Logan, $8+32 ?$.

This research was supported jointly by the Bureau of Land Management (Contract 52500-CTS-16) and the Utah Agricultural Experiment Station, Project 412. The authors are grateful to Dr. Al Southard, Department of Soils and Biometeorology, for assistance in classification of soils. Journal paper 2291, Utah Agricultural Experiment Station.

Manuscript received April 14, 1978. originating on immense areas of wildland watersheds, and particularly rangeland watersheds.

This study deals with the application of various range improvement practices for eventual formulation of land management programs that may influence diffuse salt production from rangelands. Data on these aspects are sparse. For example, Soiseth et al. (1974), in southeastern Montana, found that soil salinity in upper soil depths was not reduced in comparison to the check on any of several panspot range sites that had been contour furrowed. Contour furrowing did, however, affect movement of salts (through increased infiltration) in the $0-$ to $10-\mathrm{cm}$ depth in the furrows. Branson et al. (1966) near Fort Peck, Montana, found that 10 years after furrowing and seeding there was a decrease in salts $(\mathrm{Ca}, \mathrm{Mg}, \mathrm{Na})$ in the upper $60 \mathrm{~cm}$ of the treated soils and an increase in salts below $60 \mathrm{~cm}$. This leaching was assumed to have taken place during the years immediately after treatment because above-ground water storage in furrows decreases with time. Wein and West (1973), near Cisco, Utah, on Chipeta series, a member of the clayey mixed calcareous mesic typic torriorthents soil family, found no accumulation of salt in contour furrows or gully plugs 5 to 6 years following construction. Their data suggested some initial early leaching of salts due to treatments, while the present trend, as evidenced by infiltration measures, suggested a possible accumulation of salts.

The specific objective of this study was to determine the effects of existing land treatments on soil profile salt concentrations and probable salt loading by surface runoff.

\section{General Description of Study Area}

Seventy-three study sites located primarily in Utah, Colorado, New Mexico, and Arizona (one site) were included in this study. The range improvement practices studied include contour furrowing (11) sites pitting ( 2 sites), pinyon-juniper chaining ( 14 sites), gully plugs (6 sites), and various sagebrush control treatments ( 40 sites). The sites in Utah (32 sites) lie primarily in Grand, Emergy, Carbon, and San Juan counties; in Colorado (12 sites), Montrose, Gunnison, Dolores, and San Miguel counties; in New Mexico (28 sites), Valencia, Sandoval, Rio Arriba, and San Juan counties; and Maricopa county in Arizona ( 1 site). General topographical, soils, and vegetation descriptions of the sites have been given previously by Hessary and Gifford (1979). More specific information is given in Table 1.

During the period from 1945 to 1978 , range improvement practices were attempted on the various study sites. The primary purpose of the improvement practices was to improve range condition through 
Table 1. Soil classification, approximate annual precipitation, and date of treatment for various range improvement practices sampled in this study.

\begin{tabular}{|c|c|c|c|}
\hline \multicolumn{2}{|l|}{ Treatment } & Order & Subgroup \\
\hline \multicolumn{4}{|c|}{ Contour furrowing } \\
\hline \multirow[t]{11}{*}{ Site } & 1 & Alfisols & Typic Cryoboralfs \\
\hline & 2 & Entisols & Ustic Torriorthents \\
\hline & 3 & Mollisols & Typic Argiborolls \\
\hline & 4 & Entisols & Typic Ustifluvents \\
\hline & 5 & Entisols & Ustic Torrifluvents \\
\hline & 6 & Entisols & Ustic Torriorthents \\
\hline & 7 & Aridisols & Typic Calciorthids \\
\hline & 8 & Aridisols & Ustollic Haplargids \\
\hline & 9 & Entisols & Typic Torriorthents \\
\hline & 10 & Entisols & Typic Torriorthents \\
\hline & 11 & Entisols & Typic Torriorthents \\
\hline
\end{tabular}

Precipitation

(mm)

Treatment

Family

year

Pitting

$\begin{array}{lll}\text { Site } & 1 & \text { Entisols } \\ & 2 & \text { Entisols }\end{array}$

Typic Torriorthents

Typic Torrifluvents

Coarse-loamy, skeletal, mixed

305

Fine, mixed, mesic

1962

Fine, mixed, frigid

1963

Fine, mixed, frigid

1963

Fine-loamy, mixed, mesic

Fine-loamy, mixed, mesic

Coarse-loamy, mixed, thermic

1965

1966

1969

1964

Fine, mixed, mesic, shallow

1968

1969

Fine, mixed, mesic, shallow

1967

Fine, mixed, mesic

1958

Sandy, mixed, mesic

254

254

1975

Pinyon-juniper

chaining

\begin{tabular}{|c|c|c|}
\hline Site & I & Mollisols \\
\hline & 2 & Aridisols \\
\hline & 3 & Mollisols \\
\hline & 4 & Aridisols \\
\hline & 5 & Aridisols \\
\hline & 6 & Aridisols \\
\hline & 7 & Aridisols \\
\hline & 8 & Aridisols \\
\hline & 9 & Mollisols \\
\hline & 10 & Aridisols \\
\hline & 11 & Mollisols \\
\hline & 12 & Mollisols \\
\hline & 13 & Mollisols \\
\hline & 14 & Aridisols \\
\hline
\end{tabular}

Typic Argiustolls

Ustollic Haplargids

Aridic Haplustolls

Ustollic Haplargids

Ustollic Haplargids

Ustollic Haplargids

Typic Calciorthids

Ustollic Calciorthids

Aridic Argiborolls

Typic Calciorthids

Typic

Typic Haplustolls

Typic Argiustolls

Ustollic Haplargids

Fine-loamy, mixed, mesic

1961

Fine-loamy, mixed, mesic

508

1960

Fine-loamy, mixed, mesic

356

356

1960

Finc-loamy, mixcd, mesic

1961

1962

Fine-loamy, mixed, mesic

356

406

356

Fine-loamy, mixed, mesic

1962

1964

1964

Loamy-skeletal, mixed, mes

330
406

356

1965

Coarse-loamy, mixed, mesic $\quad 305$

Fine-loamy, mixed, mesic $\quad 356$

Fine-loamy, mixed, mesic $\quad 356$

Fine, mixed, mesic, shallow 203

Fine-loamy, mixed, mesic, shallow 279

1968

1968

1969

1970

1971

Typic Torriorthents

Typic Torriorthents

Ustic Torriorthents

Typic Torriorthents

Typic Torriorthents

Ustic Torrifluvents

Entisols

Entisols

Sagebrush ripping

\begin{tabular}{|c|c|c|}
\hline Site & 1 & Entisols \\
\hline & 2 & Aridisols \\
\hline & 3 & Entisols \\
\hline & 4 & Entisols \\
\hline & 5 & Aridisols \\
\hline & 6 & Entisols \\
\hline & 7 & Aridisols \\
\hline & 8 & Entisols \\
\hline & 9 & Aridisols \\
\hline & 10 & Entisols \\
\hline & 11 & Entisols \\
\hline & 12 & Entisols \\
\hline & 13 & Entisols \\
\hline
\end{tabular}

Ustic Torriorthents

Typic Camborthids

Ustic Torriorthents

Typic Torrifluvents

Typic Camborthids

Typic Torriorthents

Ustic Haplargids

Ustic Torrifluvents

Ustollic Haplargids

Ustic Torriorthents

Typic Torrifluvents

Ustic Torriorthents

Ustic Torriorthents

Fine, mixed, mesic, shallow

Fine-loamy, mixed, mesic, shallow

Fine-loamy, mixed, mesic

Fine-loamy, mixed, mesic, shallow

Fine-loamy, mixed, mesic, shallow

Fine-loamy, mixed, mesic

Fine, mixed, mesic

Fine-loamy, mixed, mesic

Fine-loamy, mixed, mesic

Coarse-loamy, montmorillonitic, mesic

Fine-loamy, mixed, mesic

Fine-loamy, mixed, mesic, shallow

Fine-loamy, mixed, mesic

1963

Fine-loamy, mixed, mesic

Fine, montmorillonitic, mesic

Fine-loamy, mixed, mesic

1965

Fine, mixed, mesic

1967

Fine-loany, mixed (calcareous), mesic, shallow

Fine-loamy, mixed, mesic

Calcic Argiustolls

Ustollic Haplargids

Ustollic Haplargids

Typic Arguistolls

Typic Haploborolls

Fine-loamy, mixed, mesic

1954

Coarse-loamy, mixed, mesic

1960

Fine-loamy, mixed, mesic

1961

Fine-loamy, mixed, mesic

1962

Ustollic Haplargids

Ustic Torrifluvents

Lethic Arguistolls

Typic Calciorthids

Lithic Ustollic

Haplargids

Fine-loamy-skeletal, mixed, mesic

Sandy, mixed, mesic

Fine-loamy, mixed, mesic

Fine-loamy, mixed, mesic

1956

Fine-loamy-skeletal, mixed,

mesic 


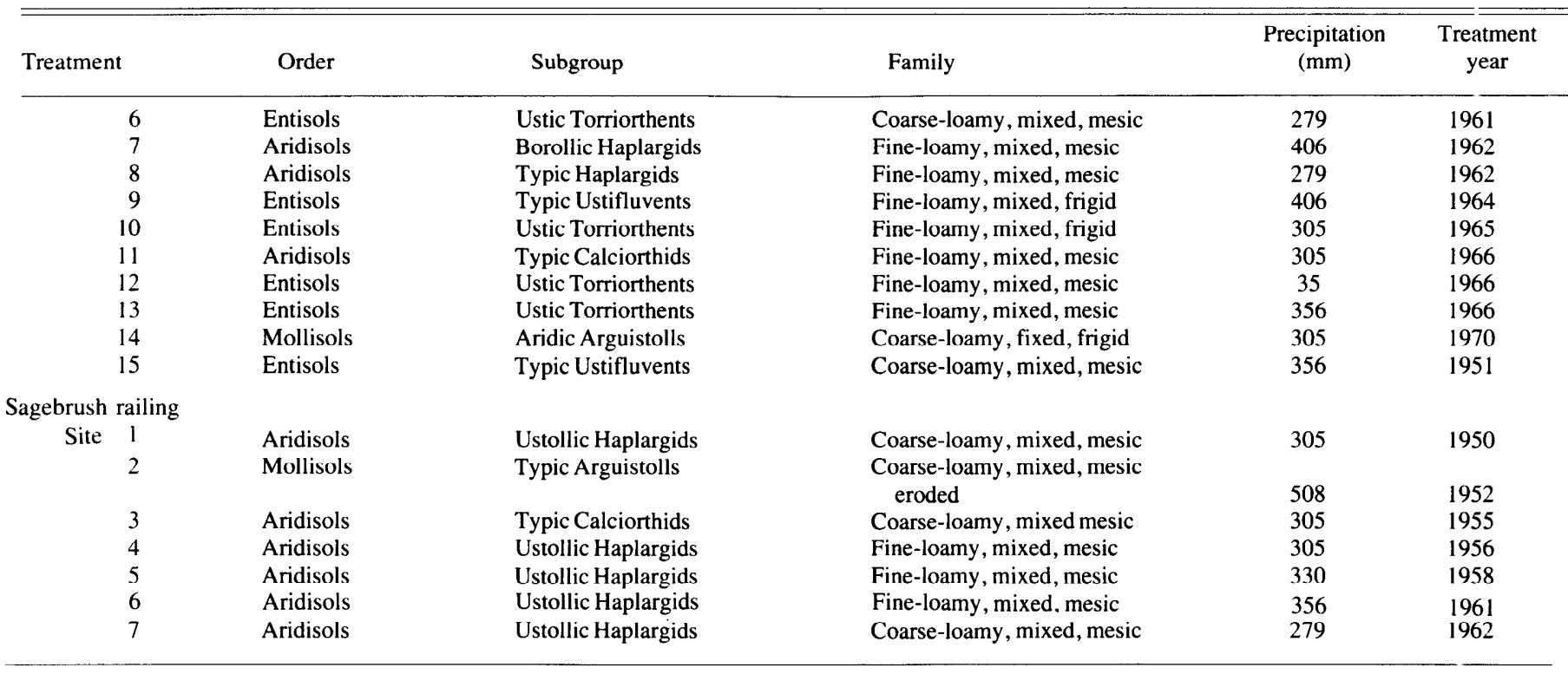

\section{Contour Furrows}

In three out of 11 contour furrow treatments, salt concentrations were significantly different among the three sampling positions (Fig. 1). Two treatments had significantly higher salt concentrations inside the furrow (at position 2), while one treatment had significantly higher salt concentrations outside the furrow (at position 1). For the three treatments there were few significant differences between ridge (spoil) and control (position 1), or spoil and furrow.

There were significant differences in salt concentrations as a function of soil depth on eight of the eleven contour furrow treatments. The general trend indicated higher salt concentrations in the two surface layers in nonsaline soils, with almost equal quantities of salt at the third and fourth depth increments. On saline soils the lower depths had higher salt concentrations than the two surface layers. There were few significant differences between the third and fourth depths.

\section{Pittings}

Analysis of variance for the two pitting treatments showed no consistent trend in salt concentrations as a function of different soil depth increments.

\section{Pinyon-Juniper Chainings}

On three of 14 pinyon-juniper sites, salt accumulations were significantly lower in the surface $0.5 \mathrm{~cm}$ soil layer of treated sites. However, the only really consistent pattern at any soil depth was the lack of difference in salt concentrations between treated and untreated sites. Based on EC measures in surface soils (maximum EC values $675 \mathrm{mmhos} / \mathrm{cm}$ ) and at greater depths (maximum EC value $445 \mathrm{mmhos} / \mathrm{cm}$ ), salt concentrations should not be a major concern on pinyon-juniper sites similar to those sampled in this study.

\section{Sagebrush Treatments}

For the most part there were few differences between treated (chained, ripped, plowed, and railed) and untreated sites, regardless of soil texture. As with indicated salt concentrations on pinyon-juniper sites, EC values as measured on sagebrush sites in this study do not indicate a need for major concern as related to salt production within major river basins.

\section{Conclusions}

During 1976 various range improvement practices, including gully plugs, contour furrowing, pitting, pinyon-juniper chaining, and various sagebrush control treatments, were studied in Utah, Colorado, New Mexico, and Arizona. Emphasis was placed on probable salt loading as a function of the above treatments. The following represents the major findings.:

1. Salt accumulations in the soil profile were significantly different among sampling positions on three of six gully plug treatments. However, the significant differences showed no consistent trend. Likewise, significant differences in salt concentrations as a function of soil depth were never consistent among the gully plug treatments. The impacts of gully plugs on diffuse salt production therefore appears mixed, perhaps somewhat site specific, and perhaps a function of age and exposure to runoff producing storms. Lack of consistent results can also be interpreted as gully plugs having only minor potential impacts on diffuse salt production, probably because the overland flow route is not a major source of diffuse salt movement, at least on the lands sampled in this study. Studies by Ponce and Hawkins (1978) and White (1977) would seem to indicate this.

2 . On contour furrowing treatments, salt concentrations on three of 11 sites were significantly different among sampling locations. Two treatments had significantly higher salt concentrations inside the furrow while one treatment had significantly higher salt concentrations outside the furrow. Based on this study it would appear that impacts of contour furrowing treatments on salt loading can be interpreted as similar to those for gully plugs. Evidence of salt accumulations within the furrows were absent on $73 \%$ of the sites sampled.

3. The only consistent pattern on pinyon-juniper chainings and the various sagebrush treatments was the general lack of difference in salt concentrations between treated and untreated sites. In general, the measured salt concentrations in surface soils of either pinyon-juniper or sagebrush sites present a problem of little concern related to salt production within major river basins. 


\section{Literature Cited}

Bouyoucos, G.J. 1962. Hydrometer method for making particle size analysis of soils. Agron. J. 54:4640465.

Branson, F.A., R.F. Miller, and I.S. McQueen. 1966. Contour furrowing, pitting and ripping on rangelands of the western United States. J. Range Manage. 19:182-190.

Gifford, G.F. 1975. Beneficial and detrimental effects on range improvement practices on runoff and erosion. In: Proc. A.S.C.E. Symp., Watershed Management, Utah State University, Aug. 11-13, Logan: 216-248.

Hessary, I., and G.F. Gifford. 1979. Impact of various range improvement practices on watershed protective cover and annual production within the Colorado River Basin. J. Range Manage. 32:134-140.

Ponce, S.L., and R.H. Hawkins 1978. Salt pickup by overland flow in the
Price River Basin, Utah. Water Resour. Bull. 14:1187-1200.

Soiseth, R.J., J.R. Wright, and J.K. Aase. 1974. Improvement of panspot (Solonetzic) range sites by countour furrowing. J. Range Manage. 27:107-110.

U.S. Salinity Laboratory Staff. 1954. Diagnosis and improvement of saline and alkali soils. U.S.D.A. Handbook No. 60.

Wein, R.W., and N.E. West. 1973. Soil changes caused by erosion control treatments on a salt desert area. Soil Sci. Soc. Amer. Proc. 37:98-103.

White, R.B. 1977. Salt production from micro-channels in the Price River Basin, Utah. MS Thesis, Utah State Univ., Logan: 121 p.

Wight, J.R. 1975. Land surface modifications and their effects on range and forest watersheds. In Proc. 5th Workshop, U.S. Australian Rangelands Panel, Boise, Idaho, June 15-22:165-174. 